\title{
Salvage HLA-haploidentical hematopoietic stem cell transplantation with post-transplant cyclophosphamide for graft failure in non- malignant disorders
}

\author{
Michael H. Albert $\mathbb{D}^{1} \cdot$ Mehtap Sirin ${ }^{2} \cdot$ Manfred Hoenig $\mathbb{D}^{2} \cdot$ Fabian Hauck $^{1,3} \cdot$ Catharina Schuetz $^{4}$. \\ Rajat Bhattacharyya ${ }^{5}$ Polina Stepensky ${ }^{6,7} \cdot$ Elad Jacoby $\mathbb{C}^{8} \cdot{\text { Tayfun Güngör } \mathbb{D}^{9} \cdot \text { Rita Beier }}^{10,11} \cdot$ Ansgar Schulz $\mathbb{\mathbb { D }}^{2}$
}

Received: 25 November 2020 / Revised: 14 April 2021 / Accepted: 21 April 2021 / Published online: 9 May 2021

(c) The Author(s) 2021. This article is published with open access

\begin{abstract}
Graft failure requires urgent salvage HSCT, but there is no universally accepted approach for this situation. We investigated T-cell replete haploidentical HSCT with post-transplantation cyclophosphamide following serotherapy-based, radiation-free, reduced intensity conditioning in children with non-malignant disorders who had rejected their primary graft. Twelve patients with primary or secondary graft failure received T-cell replete bone marrow grafts from haploidentical donors and post-transplantation cyclophosphamide. The recommended conditioning regimen comprised rituximab $375 \mathrm{mg} / \mathrm{m}^{2}$, alemtuzumab $0.4 \mathrm{mg} / \mathrm{kg}$, fludarabine $150 \mathrm{mg} / \mathrm{m}^{2}$, treosulfan $20-24 \mathrm{~g} / \mathrm{m}^{2}$ and cyclophosphamide $29 \mathrm{mg} / \mathrm{kg}$. After a median follow-up of 26 months (7-95), eleven of twelve patients (92\%) are alive and well with complete donor chimerism in ten. Neutrophil and platelet engraftment were observed in all patients after a median of 18 days (15-61) and 39 days (15-191), respectively. Acute GVHD grade I was observed in 1/12 patients (8\%) and mild chronic GVHD in 1/12 patients (8\%). Viral reactivations and disease were frequent complications at $75 \%$ and $42 \%$, respectively, but no death from infectious causes occurred. In summary, this retrospective analysis demonstrates that a post-transplantation cyclophosphamide-based HLAhaploidentical salvage HSCT after irradiation-free conditioning results in excellent engraftment and overall survival in children with non-malignant diseases.
\end{abstract}

These authors contributed equally: Michael H. Albert, Mehtap Sirin

Michael H. Albert

malbert@med.lmu.de

1 Department of Pediatrics, Dr. von Hauner Children's Hospital, University Hospital, LMU Munich, Munich, Germany

2 Department of Pediatrics and Adolescent Medicine, University Medical Center Ulm, Ulm, Germany

3 German Centre for Infection Research (DZIF), Munich, Germany

4 Department of Pediatrics, Medizinische Fakultät Carl Gustav Carus, Technische Universität Dresden, Dresden, Germany

5 Haematology Oncology Service, Department of Paediatric subspecialties, KK Women's and Children's Hospital, Bukit Timah, Singapore

6 Faculty of Medicine, Hebrew University of Jerusalem, Jerusalem, Israel

\section{Introduction}

Graft failure (GF) is a rare but severe complication after hematopoietic stem cell transplantation (HSCT). GF is relatively infrequent in leukemia patients and after matched related donor HSCT, but occurs in up to $10 \%$ of patients

7 The Department of Bone Marrow Transplantation, Hadassah Medical Center, Jerusalem, Israel

8 Division of Pediatric Hematology Oncology and BMT, The Edmond and Lily Safra Children's Hospital, Sheba Medical Center, and Sackler Faculty of Medicine, Tel Aviv University, Tel Aviv, Israel

9 Department of Hematology/Oncology/Immunology, Genetherapy, and Stem Cell Transplantation, University Children's Hospital Zürich - Eleonore Foundation \& Children's Research Center (CRC), Zürich, Switzerland

10 Department of Pediatric Hematology and Oncology, University Duisburg-Essen, Essen, Germany

11 Department of Pediatric Hematology and Oncology, Hannover Medical School, Hannover, Germany 
with non-malignant disorders after cord blood, matched unrelated (MUD) or haploidentical HSCT [1-5].

Primary GF is defined as failure of sustained hematopoiesis (absolute neutrophil count $<500 / \mu 1$, hemoglobin $<80 \mathrm{~g} / \mathrm{L}$, platelets $<20 \mathrm{G} / \mathrm{L}$ ) by day +28 or +42 (cord blood) after HSCT. Secondary GF occurs after initial donor cell engraftment, usually later than $\mathrm{d}+28$. Graft rejection is defined as immune-mediated rejection of donor cells and can result in primary as well as secondary GF [6]. Poor graft function on the other hand describes cytopenia occurring after $d+28$ in the presence of donor chimerism, which can often be successfully treated with a stem cell boost [7].

The etiology of GF is multifactorial, with contributing factors such as underlying disease, alloimmunization with anti-HLA antibodies, intensity of conditioning, drug toxicity, viral infections, infused hematopoietic stem cell dose, graft manipulation, serotherapy, and degree of HLA-(mis) matching $[5,8,9]$. Patients with non-malignant diseases have not been exposed to chemotherapy prior to conditioning for their first HSCT and are therefore at higher risk for GF than patients with malignant diseases $[1,4,5]$. As a graft-versus-leukemia effect is not needed to cure these diseases, in vivo and ex vivo T-cell depletion of the graft is often more stringent in these HSCTs and may contribute to graft rejection/failure, especially in patients with inborn errors and intact/residual $\mathrm{NK}$ and $\mathrm{T}$ cell function.

Prolonged pancytopenia and immunosuppression after GF represent a life-threatening emergency. If available, an unconditioned CD34+-selected stem cell boost from the original donor may be successful in select patients with poor graft function and predominant donor chimerism [10]. In situations of acute GF/rejection and in the absence of a cryopreserved autograft, a salvage second allogeneic HSCT is usually the only lifesaving treatment. However, there is no universally accepted approach for donor choice or conditioning regimen, and recruitment of a second unrelated donor is often not possible in a timely manner. At least one HLA-haploidentical family donor is usually readily available for almost all patients, especially for pediatric patients [11]. Recently, it was demonstrated that the outcomes and GVHD rates of haploidentical HSCT with post-transplant cyclophosphamide (pTCy) were comparable to those with matched related or unrelated donors in adult and pediatric patients with leukemia $[12,13]$, as well as in pediatric patients with inborn errors [14-16]. PTCy is potently tolerogenic by selectively depleting alloreactive $\mathrm{T}$ cells responsible for GVHD and graft rejection, while sparing stem cells, regulatory $\mathrm{T}$ cells and non-alloreactive resting $\mathrm{T}$ cells, which are needed for adaptive immunity e.g. against viruses [17]. Two groups have recently reported encouraging results in children with leukemia and GF using a low-dose total body irradiation
(TBI) or total-lymphoid irradiation (TLI) based reconditioning strategy $[18,19]$. However, the appropriateness of ionizing irradiation in this situation can be questioned for several reasons including particular concerns about long-term toxicity especially in young children with non-malignant disease [20].

We therefore hypothesized that the combination of a chemotherapy-based, immunoablative re-conditioning containing serotherapy followed by $\mathrm{T}$ cell replete haploidentical bone marrow with pTCy would be able to overcome engraftment barriers in children with nonmalignant disorders and GF. We designed a salvage HSCT protocol combining these properties, and present here the results of an international retrospective analysis of this approach in seven centers.

\section{Methods}

\section{Definitions}

Engraftment was defined as the first of three consecutive days to reach an absolute neutrophil count (ANC) of $>500 / \mu 1$ or platelets of $>20.000 / \mu$ l without transfusion support. Primary GF was defined as not having achieved neutrophil engraftment until day +28 . Secondary GF was defined as loss of donor engraftment after day +28 , with or without associated ANC $<500 / \mu 1$. Patients with antiHLA antibodies directed against an HLA antigen present in the donor were defined as anti-HLA donor-specific antibody (DSA) positive. Staging of acute GVHD was performed according to modified Glucksberg criteria and chronic GVHD was staged according to NIH consensus standards $[21,22]$.

\section{Treatment recommendations}

The treatment protocol was designed for patients with nonmalignant diseases and GF after a previous allogeneic HSCT. Recommended conditioning consisted of rituximab $375 \mathrm{mg} / \mathrm{m}^{2}$ (day -10 ), alemtuzumab $0.4 \mathrm{mg} / \mathrm{kg}$ (days -9 to -8 ), fludarabine $150 \mathrm{mg} / \mathrm{m}^{2}$ (days -7 to -3 ), treosulfan 24 $\mathrm{g} / \mathrm{m}^{2}$ (days -5 to -4 ) and cyclophosphamide $29 \mathrm{mg} / \mathrm{kg}$ (days -3 to -2 ), followed by unmanipulated bone marrow from HLA-haploidentical family donors (Fig. 1). GVHD prophylaxis was recommended as cyclophosphamide $2 \times 50 \mathrm{mg} / \mathrm{kg}$ on days +3 and +4 , tacrolimus from day +5 , tapered after day +100 , plus mycophenolate mofetil (MMF) from day +5 to day +35 . Erythrocyte or plasma depletion was performed for AB0 incompatibility. Supportive care was carried out according to local institutional standards and contained antiviral, mold-active antifungal and Pneumocystis jirovecii prophylaxis in all centers. 
Fig. 1 Recommended conditioning regimen. $\mathrm{Cy}$ : cyclophosphamide; MMF: mycophenolate mofetil.

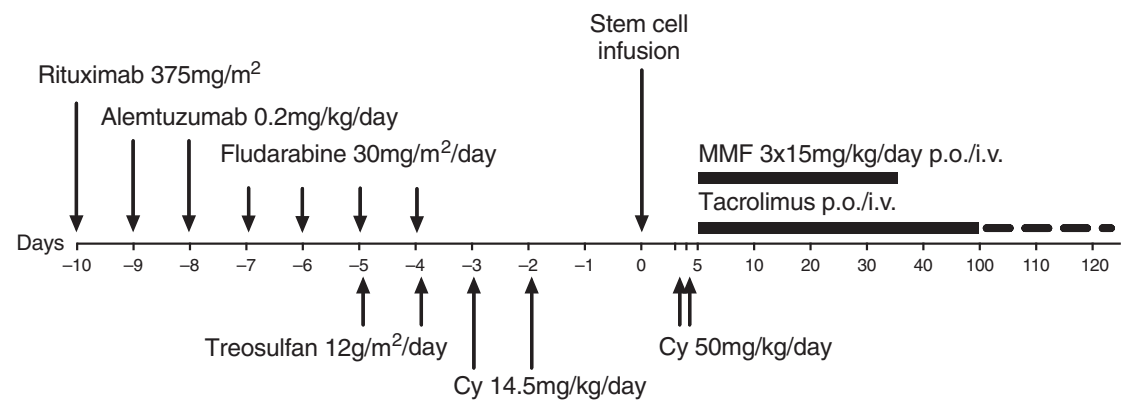

\section{Data collection}

The treatment recommendations for haploidentical salvage HSCT were devised in Munich, Germany, and disseminated upon request to the participating centers. We retrospectively collected data from 12 consecutive GF patients transplanted between 1st of January 2012 and 31st of July 2020 at six centers (Munich, Ulm, Essen, Singapore, Jerusalem, and Ramat Gan), representing all pediatric patients with nonmalignant diseases presenting with GF at these centers during that time period. Patient caregivers consented to retrospective file-based data collection via the ethically approved "Pädiatrisches Register für Stammzelltransplantation" (PRST) in Munich, Ulm, and Essen, and local ethics approval was obtained for anonymized data transfer at the other centers if required by local standards.

\section{Results}

\section{Patient characteristics, previous HSCTs and graft failure}

We report on 12 patients from seven centers, who underwent salvage haploidentical HSCT following the proposed regimen. All patients suffered from non-malignant diseases, either inborn errors of immunity $(n=7)$ or bone marrow failure syndromes $(n=5)$. All had undergone previous HSCT at a median age of 4.5 years (range 1.0-14.7) from a matched unrelated (MUD; $n=4$ ) or a haploidentical mismatched family donor (MMFD; $n=8$ ) after reduced intensity (RIC; $n=6$ ) or myeloablative (MAC; $n=6$ ) conditioning regimens. None of the patients had detectable donor-specific anti-HLA-antibodies against their first donor. All patient and previous HSCT characteristics are detailed in Table 1.

Seven patients presented with primary and five with secondary GF. After GF, two patients had received a second conditioned HSCT from the original donor; one received an unconditioned bone marrow boost with previously cryopreserved cells. Neither resulted in detectable donor engraftment. Three patients had a diagnosis of GF before $\mathrm{d}$ +28 (pts 6, 7, and 11). All of them experienced a shortlived increase in white blood cells with some degree of donor chimerism followed by high fevers and a drop of counts and disappearance of donor chimerism. Therefore, the diagnosis of GF was "prematurely" established before $\mathrm{d}$ +28 in these patients. All patients had $<50 \%(n=2)$ or undetectable $(n=10)$ peripheral blood donor chimerism at time of GF (Table 1).

\section{Salvage HSCT}

At a median of 46 days (29-115) after their previous HSCT, 12 patients underwent salvage HSCT with an unmanipulated graft from an HLA-haploidentical family donor $(n=11)$ or a mismatched unrelated donor $(8 / 10$ HLA match; $n=1$ ). An alternative donor was chosen for the salvage HSCT in 11/12 patients. Slight modifications of the suggested regimen (Fig. 1) were possible by institutional preference, but a backbone of a treosulfan/fludarabine-based, radiation-free, reduced intensity conditioning followed by T-cell replete mismatched donor grafts and GVHD prophylaxis with pTCy, calcineurin inhibitor and MMF was maintained throughout the cohort. Patient 11 received ATG instead of alemtuzumab because the latter was not available in his country. Conditioning consisted of fludarabine, reduced-dose treosulfan, lowdose cyclophosphamide and T cell-directed serotherapy in all patients. Eleven patients also received a single dose of rituximab. Detailed dosing of the conditioning regimen can be found in the methods section and Table 2. The grafts were unmanipulated bone marrow $(n=11)$ or PBSC $(n=1)$ grafts with a median total nucleated cell count of $9.2 \times 10^{8} / \mathrm{kg}(2.9-13.8), \mathrm{CD} 34^{+}$count of 7.8 $\times 10^{6} / \mathrm{kg}(2.9-19.7)$ and $\mathrm{CD}^{+}$count of $8.4 \times 10^{6} / \mathrm{kg}$ (4.9-38.7) (Fig. 2). GVHD prophylaxis consisted of cyclophosphamide $50 \mathrm{mg} / \mathrm{kg} / \mathrm{d}$ on days +3 and +4 , followed by mycophenolate mofetil (MMF) and tacrolimus $(n=11)$ or cyclosporine A (CSA, $n=1)$ starting on day +5 . Immunosuppression was stopped after a median time of 110 days after salvage HSCT (range 56-252). 


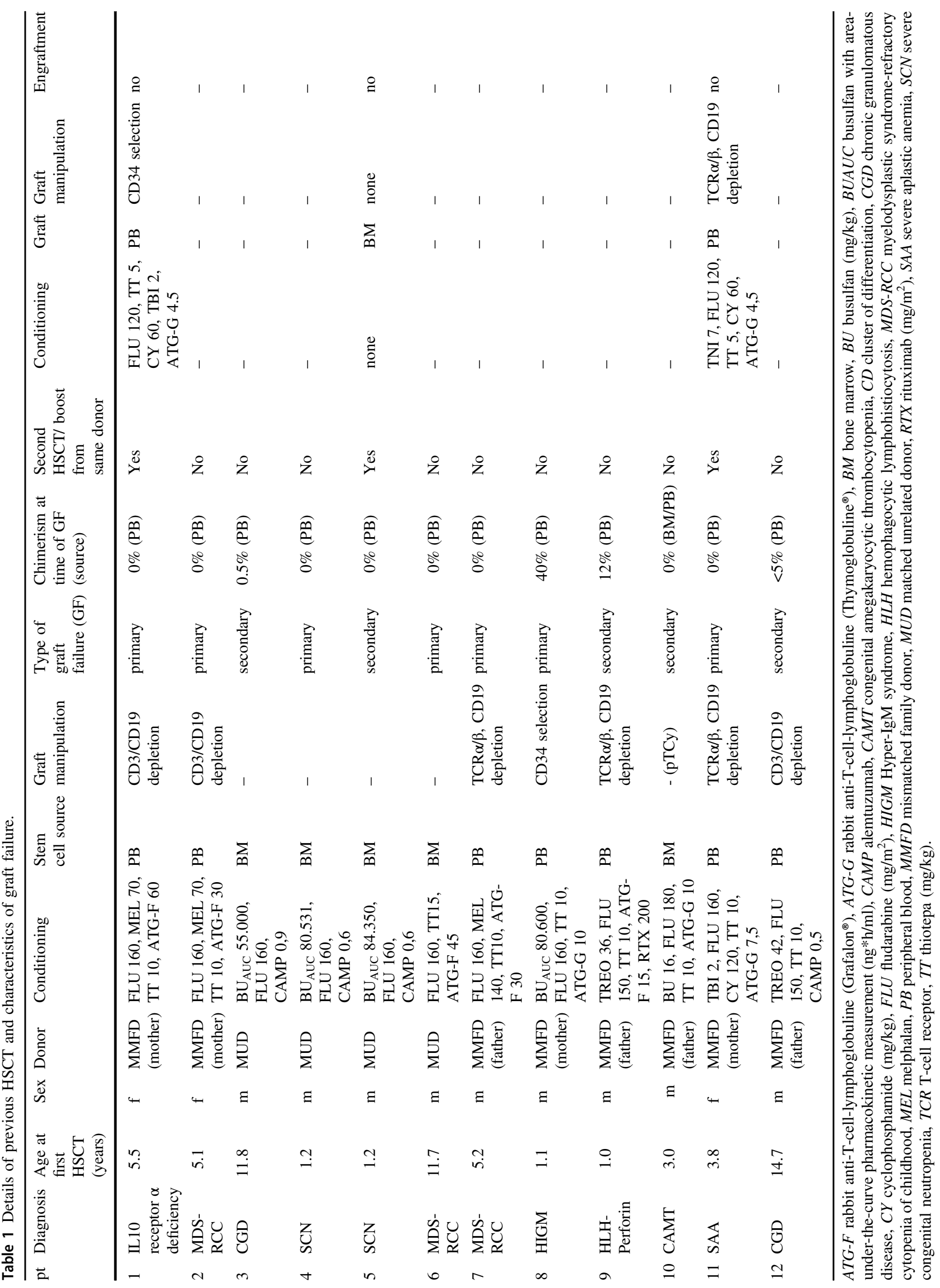




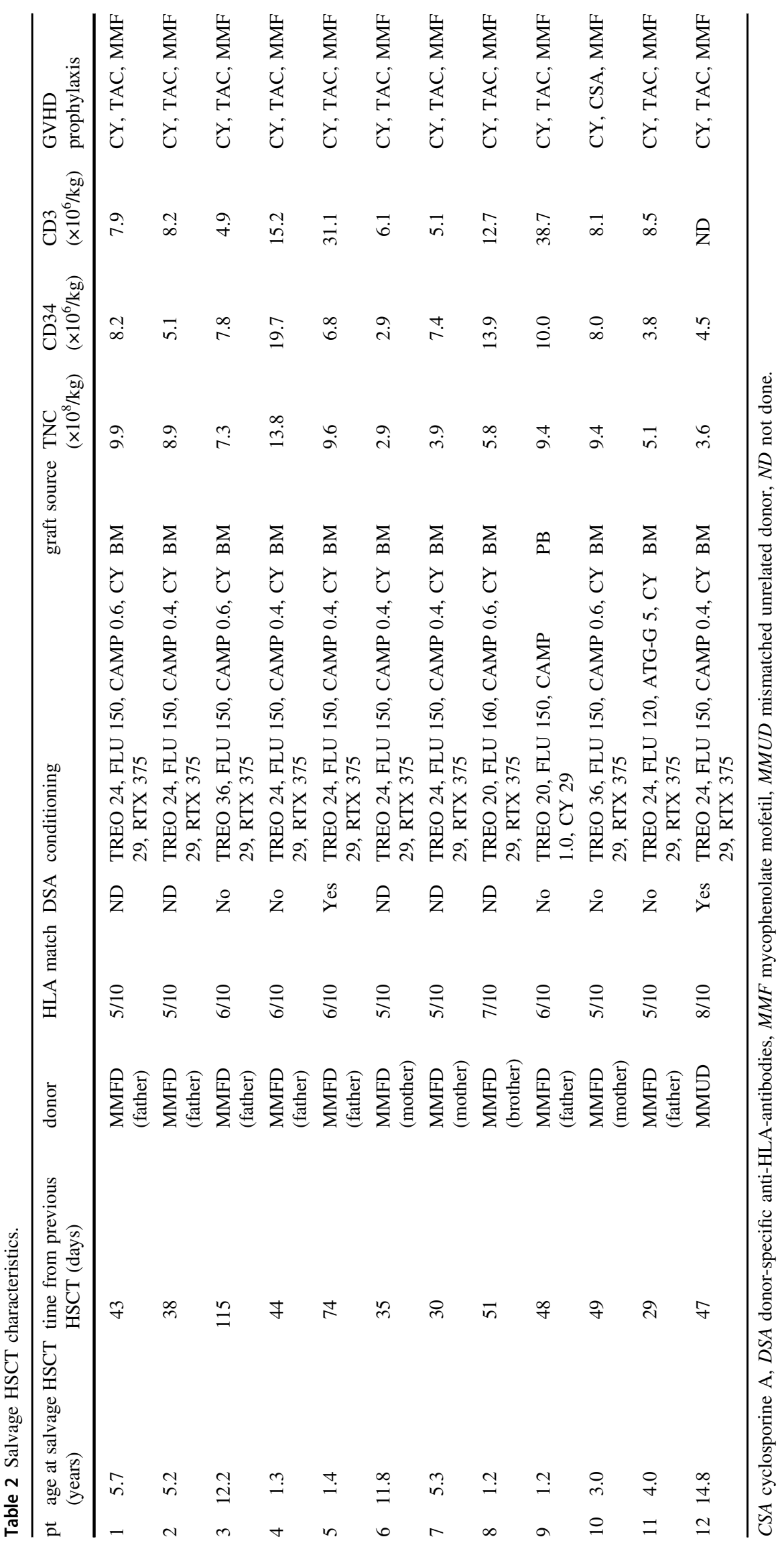


Fig. 2 Graft composition, engraftment and cellular immune reconstitution. Graft composition (A), engraftment kinetics $(\mathbf{B})$, and immune reconstitution $(\mathbf{C}-\mathbf{F})$ after salvage HSCT. a

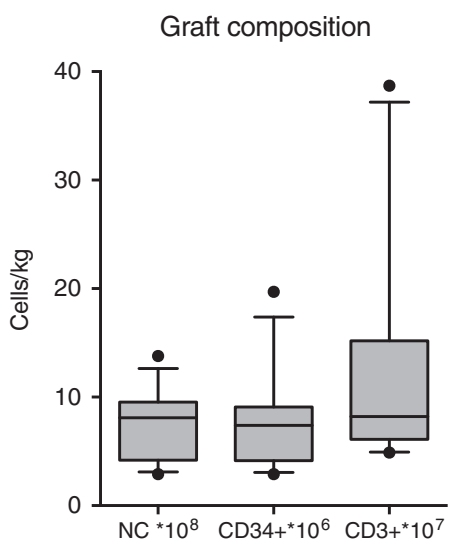

C
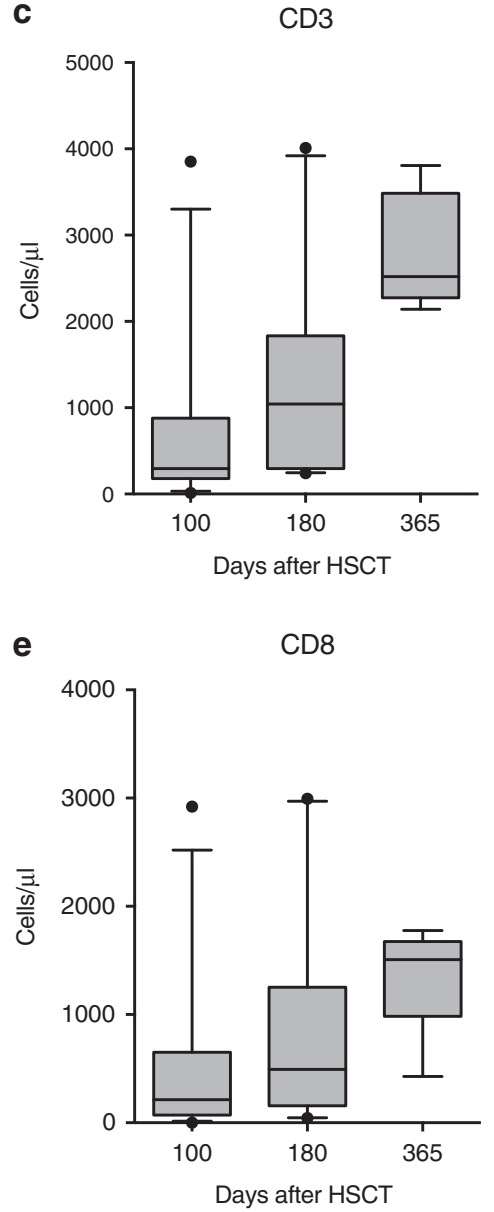

b

Engraftment

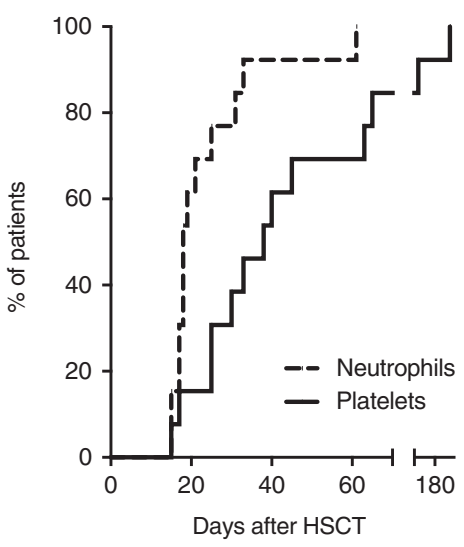

d

CD4

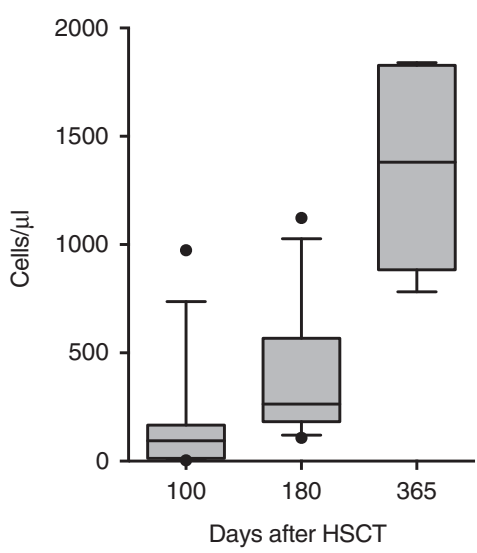

f

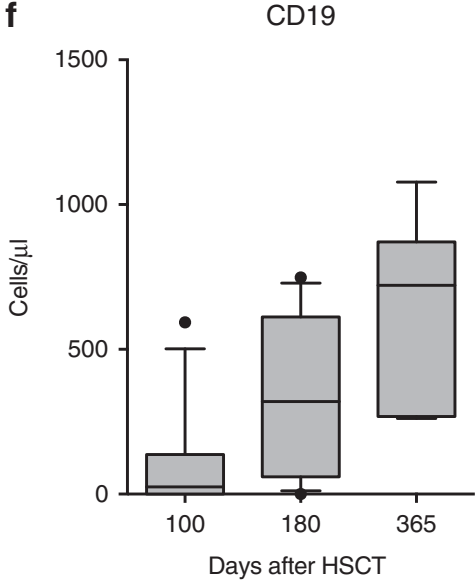

Engraftment, survival, and immune reconstitution

Neutrophil and platelet engraftment after salvage HSCT were observed in all patients after a median of 18 days (15-61) and 39 days (15-191), respectively (Fig. 2). After a median follow-up of 26 months (7-95) eleven of twelve patients $(92 \%)$ are alive, well and disease-free with complete donor chimerism in $10 / 11$. One patient died on day
+259 after salvage HSCT from radiologically determined chronic lymphocytic inflammation with pontine perivascular enhancement responsive to steroids (CLIPPERS) syndrome [23] (Table 3). Cellular immune reconstitution was timely in our cohort with a median of $298 / \mu \mathrm{LD} 3^{+}$

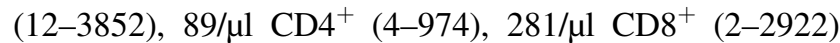

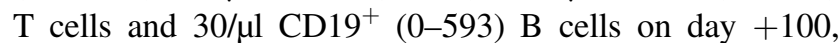

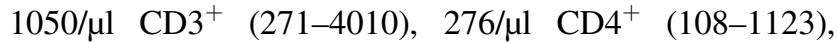




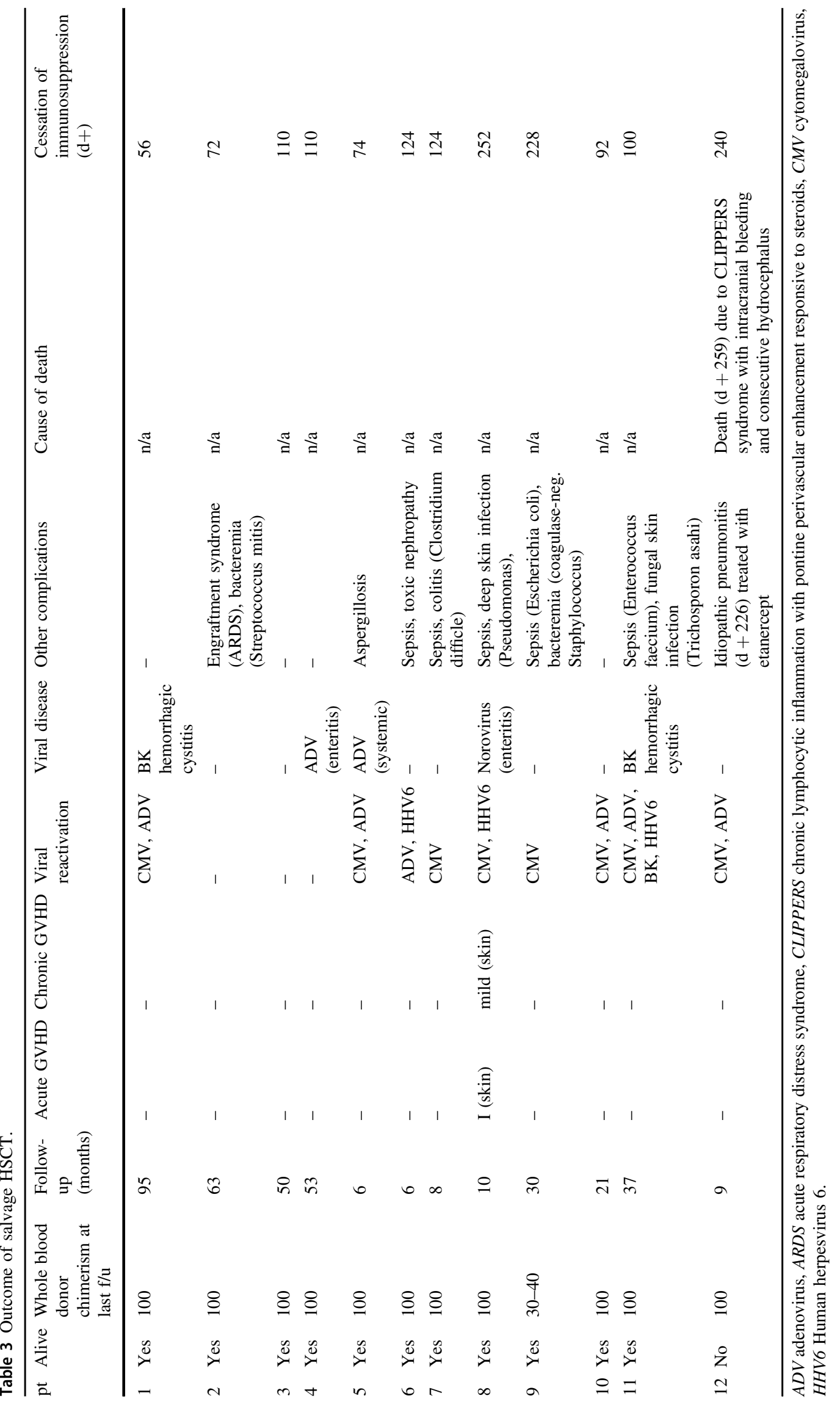




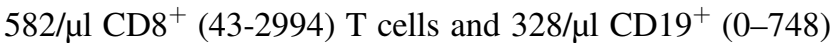
$\mathrm{B}$ cells on day +180 , and $2635 / \mu \mathrm{CD}^{+}(2142-3806)$,

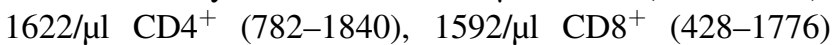
$\mathrm{T}$ cells and $800 / \mu \mathrm{LD} 19^{+}(261-1078)$ cells on day +365 (Fig. 2). All patients were off immunoglobulin substitution at last follow-up and no patient required substitution after $\mathrm{d}+180$.

\section{Toxicity and GVHD}

Toxicity greater than CTCAE grade 2 was observed in one patient with elevated transaminases $\geq 3$ times above the upper limit of normal. No patient developed veno-occlusive disease (VOD; $n=2$ with defibrotide prophylaxis) or thrombotic microangiopathy. Viral reactivation with asymptomatic viremia was the most frequent complication and occurred in nine out of twelve patients $(75 \%)$ with detection of CMV ( $n=8)$, ADV (6), HHV6 (3), and BK virus (2). Five patients (42\%) had symptomatic viral infections (ADV 2, BK 2, norovirus 1). All viral reactivations/infections either resolved spontaneously or were successfully treated. Bacterial sepsis or bacteremia were observed in five and two patients, respectively. Other complications are detailed in Table 3. GVHD was almost negligible with acute GVHD grade I (skin stage 2) observed in $1 / 12$ patients (8\%) and mild chronic GVHD (skin only) in $1 / 12$ patients $(8 \%)$, which was resolved at last follow-up in all patients (Table 3 ).

\section{Discussion}

GF after allogenic HSCT is associated with high mortality rates because of the risk for severe infections during prolonged aplasia and organ dysfunction after conditioning ${ }^{1-3}$. The risk for GF is reported to be up to 3-fold higher in nonmalignant diseases. GF without autologous reconstitution of hematopoiesis is a life-threatening emergency requiring a timely salvage HSCT. In this report, we describe 12 patients with non-malignant diseases, who received a salvage HSCT with $\mathrm{T}$ replete grafts from mismatched donors using a modified Baltimore protocol without total body irradiation [24]. All patients engrafted and 11/12 (92\%) survived and are alive and well.

In the event of GF, a salvage transplantation is crucial to establish a functioning donor hematopoiesis as quickly as possible. In most instances, it is challenging to find a matched alternative donor in a timely manner. Unrelated umbilical cord blood grafts are usually readily available but implicate a high risk for second GF and infection-related mortality because of prolonged immune reconstitution [25]. Therefore, HLA-haploidentical related donors represent an attractive alternative donor source. Because immune-mediated processes are known to play a role in the rejection of donor stem cells by the recipient, we aimed at maximizing the tolerogenic capacity of the conditioning regimen, while reducing the toxicities associated with intensive myeloablation, which is not needed in patients with near aplastic marrow. In addition to the immunosuppressive quality of fludarabine, we incorporated serotherapy directed at remaining immunocompetent recipient T-, B- and NK-cells. The dose of alemtuzumab in our regimen was low and applied rather early before graft infusion in order to minimize the effect on donor graft facilitating cells. While the low absolute dose administered not later than day -8 can be expected to result in sub-Tcell-lympholytic levels at the time of graft infusion [26, 27], it cannot be excluded that because of the low lymphocyte counts of the recipients a longer than usual half-life of alemtuzumab and rituximab could have resulted. In theory, this could explain the relatively high rate of viral reactivations observed in this cohort, but there was no apparent detrimental effect on quantitative T- and B-cell reconstitution and blood levels of serotherapy agents were not monitored in our patients. Alemtuzumab not only targets $\mathrm{T}$ cells but also B cells and plasma cells [28]. Still, we chose to recommend the additional application of rituximab-also in DSA negative patients-due to the anticipated but hypothetical need for maximal disruption of humoral anti-donor immunity of the recipient including the hypothetical role of non-HLA antidonor antibodies [29]. However, the non-controlled nature of the study does not allow drawing a firm conclusion on whether the addition of serotherapy was relevant for the excellent overall outcome in these patients.

A number of case series of successful salvage HSCT for GF employing different conditioning regimens and donor sources have been published, but there is no universally accepted approach for this situation. Various small series reported encouraging results with overall survival (OS) ranging from $36 \%$ to $63 \%$, in adults with hematologic malignancies [30-32] to $96 \%$ in adults with aplastic anemia and matched sibling donors (MSD) [33]. Of particular interest, Teltschik et al. reported on eleven pediatric patients predominantly with leukemia who experienced GF [18]. The salvage HSCT was performed after total nodal irradiation (TNI)-based conditioning using T-cell depleted peripheral blood stem cell grafts from HLA-haploidentical donors. All patients engrafted and the OS was $68 \%$ with little severe acute (11\% grade III), no severe chronic GVHD, and transplant related mortality (TRM) of $11 \%$ [18]. Park et al used a similar approach in ten pediatric patients with primary GF after HSCT for severe aplastic anemia, leukemia, or MDS. They also infused T-cell depleted grafts (with $\mathrm{CD} 3$ or $\mathrm{CD} 3 / \mathrm{CD} 19$ depletion) from MMFD after fludarabine/cyclophosphamide conditioningwith the addition of TBI in three patients-and reported a 2year OS of $88 \%$ with $\geq$ grade III acute GVHD of $25 \%$, no 
severe chronic GVHD, and a TRM of $10 \%$ [34]. These results compare well with our cohort, which exhibits an OS of $92 \%$, no severe acute or chronic GVHD, and a TRM of $8 \%$. Of note, all three approaches resulted in $100 \%$ engraftment after salvage HSCT, but in our cohort, this was achieved without irradiation as part of the conditioning regimen. Because of the perceived long-term detrimental effects, irradiation remains controversial in children, especially in those with non-malignant diseases. Furthermore, in the setting of bone marrow aplasia after GF, it might be worth considering that irradiation implicates that the patient has to leave the protective isolation of the transplant unit several times, and that smaller infants need sedation or general anesthesia to tolerate the irradiation procedure. The very low rates of severe acute and chronic GVHD using haploidentical donors in all three cohorts is encouraging, given the degree of HLA-disparity. Of note, in our cohort the only patient who died had a mismatched unrelated donor. This donor was chosen because the mother was a disease carrier, the father was the donor for the previous HSCT, and a donor change was intended. It remains speculative whether an HLA-haploidentical donor with one genoidentical haplotype would have been advantageous in this setting.

Like any other retrospective, multi-center study, our analysis is prone to selection bias and heterogeneity of patients and transplant centers. However, all pediatric patients with non-malignant diseases presenting with GF at the participating centers during this period were included into this analysis, limiting a particular selection bias in this respect.

It is well established that donor $\mathrm{T}$ cells play an important role in promoting engraftment [35], which is why we chose a T-cell replete instead of an in vivo T-cell depleted graft. In fact, two of our patients had undergone a second conditioned in vivo T-cell depleted MMFD HSCT, with either one of the regimens proposed by Teltschik et al and Park et al. Both did not result in engraftment. The role of changing the donor for a second HSCT remains controversial [36]. In our cohort, all but one patient received their salvage HSCT from a different donor. This was intended in order to account for hypothetical, undetectable donor-specific immunity of the recipient. Even though the only patient who was re-transplanted with the same donor is also the only one with incomplete donor chimerism at last follow-up, it remains speculative whether any donor-specific immunity outside of DSA may have played a role here.

Immune reconstitution after HSCT with in vitro T-cell depletion with $\mathrm{CD} 3 / \mathrm{CD} 19$ depletion or $\mathrm{CD} 34$ positive selection is generally expected to be slow [37]. Accordingly, Park et al observed high rates of viral reactivation and disease in $90 \%$ and $50 \%$ of patients, respectively [34]. T cell receptor alpha/beta depleted PBSC grafts may result in faster T-cell recovery [38]. However, exact rates of viral reactivations/infections per patient were not reported by Teltschik et al, but the rate of infectious toxicity of grade 3-4 CTCAE was 48\% [18]. In the pTCy protocol, a T-cell replete graft is transfused, alloreactive $\mathrm{T}$ cells are depleted in vivo by cyclophosphamide, and resting memory $\mathrm{T}$ cells responsible for infection control are presumably spared [17]. Nevertheless, viral reactivations were also frequent in $75 \%$ of patients in our cohort, and $42 \%$ experienced viral disease either successfully treated with antivirals or spontaneously resolving without sequela or chronic morbidity. This may be explained by the overall immunosuppressive nature of this regimen and/or by some degree of post HSCT immunosuppression caused by the serotherapy in our regimen as discussed above. However, quantitative immune reconstitution of $\mathrm{T}$ cells in our cohort was comparable to what is expected after a MSD or MUD HSCT and faster than after in vitro $\mathrm{T}$ cell depletion by $\mathrm{CD} 34$ positive selection [38, 39]. Likely, because of the low dose of treosulfan and the absence of irradiation, there was little acute toxicity apart from infections, especially no VOD nor severe mucositis. This stands in contrast to the TNI-based protocol employed by Teltschik et al where grade 3-4 mucositis was observed in $84 \%$ of patients [18].

In summary, we demonstrate that a pTCy-based HLAhaploidentical HSCT after an irradiation-free conditioning results in excellent engraftment and overall survival in this cohort of children with non-malignant diseases, who had experienced GF. Even though this is a non-comparative and retrospective analysis with a limited number of patients, it shows that early salvage HSCT from MMFD with pTCy is a feasible approach in the event of GF.

Funding Open Access funding enabled and organized by Projekt DEAL.

\section{Compliance with ethical standards}

Conflict of interest M.H.A. has received reimbursement for attending conferences from Medac. All other authors declare no competing financial interests in relation to the work described.

Publisher's note Springer Nature remains neutral with regard to jurisdictional claims in published maps and institutional affiliations.

Open Access This article is licensed under a Creative Commons Attribution 4.0 International License, which permits use, sharing, adaptation, distribution and reproduction in any medium or format, as long as you give appropriate credit to the original author(s) and the source, provide a link to the Creative Commons license, and indicate if changes were made. The images or other third party material in this article are included in the article's Creative Commons license, unless indicated otherwise in a credit line to the material. If material is not included in the article's Creative Commons license and your intended use is not permitted by statutory regulation or exceeds the permitted use, you will need to obtain permission directly from the copyright holder. To view a copy of this license, visit http://creativecommons. org/licenses/by/4.0/. 


\section{References}

1. Champlin RE, Horowitz MM, van Bekkum DW, Camitta BM, Elfenbein GE, Gale RP, et al. Graft failure following bone marrow transplantation for severe aplastic anemia: risk factors and treatment results. Blood. 1989;73:606-613. e-pub ahead of print 1989/ $02 / 01$

2. McCann SR, Bacigalupo A, Gluckman E, Hinterberger W, Hows J, Ljungman P, et al. Graft rejection and second bone marrow transplants for acquired aplastic anaemia: a report from the Aplastic Anaemia Working Party of the European Bone Marrow Transplant Group. Bone Marrow Transplant. 1994;13:233-237. e-pub ahead of print 1994/03/01

3. Kongtim P, Cao K, Ciurea SO. Donor specific Anti-HLA antibody and risk of graft failure in haploidentical stem cell transplantation. Adv Hematol. 2016;2016:4025073 https://doi.org/10.1155/2016/ 4025073. e-pub ahead of print 2016/02/24

4. Booth C, Veys P. T cell depletion in paediatric stem cell transplantation. Clin Exp Immunol. 2013;172:139-147. https://doi.org/ 10.1111/cei.12004. e-pub ahead of print 2013/04/12

5. Olsson R, Remberger M, Schaffer M, Berggren DM, Svahn BM, Mattsson J, et al. Graft failure in the modern era of allogeneic hematopoietic SCT. Bone Marrow Transplant. 2013;48:537-543. https://doi.org/10.1038/bmt.2012.239. e-pub ahead of print 2012/ $12 / 12$

6. Valcarcel D, Sureda A. Graft failure. In: Carreras E, Dufour C, Mohty M, Kröger N, editors. The EBMT Handbook. EBMT; 2019. p. 307-313.

7. Klyuchnikov E, El-Cheikh J, Sputtek A, Lioznov M, Calmels B, Furst S, et al. CD34(+)-selected stem cell boost without further conditioning for poor graft function after allogeneic stem cell transplantation in patients with hematological malignancies. Biol Blood Marrow Transplant: J Am Soc Blood Marrow Transplant. 2014;20:382-386. https://doi.org/10.1016/j.bbmt.2013.11.034. epub ahead of print 2013/12/11

8. Cluzeau T, Lambert J, Raus N, Dessaux K, Absi L, Delbos F, et al. Risk factors and outcome of graft failure after HLA matched and mismatched unrelated donor hematopoietic stem cell transplantation: a study on behalf of SFGM-TC and SFHI. Bone Marrow Transplant. 2016;51:687-691. https://doi.org/10.1038/ bmt.2015.351. e-pub ahead of print 2016/02/09

9. Olsson RF, Logan BR, Chaudhury S, Zhu X, Akpek G, Bolwell $B J$, et al. Primary graft failure after myeloablative allogeneic hematopoietic cell transplantation for hematologic malignancies. Leukemia. 2015;29:1754-1762. https://doi.org/10.1038/leu.2015. 75. e-pub ahead of print 2015/03/17

10. Booth C, Ribeil JA, Audat F, Dal-Cortivo L, Veys PA, Thrasher AJ, et al. CD34 stem cell top-ups without conditioning after initial haematopoietic stem cell transplantation for correction of incomplete haematopoietic and immunological recovery in severe congenital immunodeficiencies. Br J Haematol. 2006;135:533-537. https://doi.org/10.1111/j.1365-2141.2006.06333.x. e-pub ahead of print 2006/10/24

11. Kwon M, Bailén R, Díez-Martín JL. Evolution of the role of haploidentical stem cell transplantation: past, present, and future. Expert Rev Hematol. 2020: 1-16. e-pub ahead of print 2020/08/05; https://doi.org/10.1080/17474086.2020.1796621

12. Nagler A, Ruggeri A. Haploidentical stem cell transplantation (HaploSCT) for patients with acute leukemia-an update on behalf of the ALWP of the EBMT. Bone Marrow Transplant. 2019;54:713-718. https://doi.org/10.1038/s41409-019-0610-5. epub ahead of print 2019/08/23

13. Klein OR, Buddenbaum J, Tucker N, Chen AR, Gamper CJ, Loeb $\mathrm{D}$, et al. Nonmyeloablative haploidentical bone marrow transplantation with post-transplantation cyclophosphamide for pediatric and young adult patients with high-risk hematologic malignancies. Biol Blood Marrow Transplant: J Am Soc Blood Marrow Transplant. 2017;23:325-332. https://doi.org/10.1016/j. bbmt.2016.11.016. e-pub ahead of print 2016/11/27

14. Kurzay M, Hauck F, Schmid I, Wiebking V, Eichinger A, Jung E, et al. T-cell replete haploidentical bone marrow transplantation and post-transplant cyclophosphamide for patients with inborn errors. Haematologica. 2019;104:e478-e482. https://doi.org/10. 3324/haematol.2018.215285. e-pub ahead of print 2019/03/09

15. Neven B, Diana JS, Castelle M, Magnani A, Rosain J, Touzot F, et al. Haploidentical hematopoietic stem cell transplantation with post-transplant cyclophosphamide for primary immunodeficiencies and inherited disorders in children. Biol Blood Marrow Transplant: J Am Soc Blood Marrow Transplant. 2019;25:1363-1373. https://doi. org/10.1016/j.bbmt.2019.03.009. e-pub ahead of print 2019/03/17

16. Osumi T, Yoshimura S, Sako M, Uchiyama T, Ishikawa T, Kawai $\mathrm{T}$, et al. Prospective study of allogeneic hematopoietic stem cell transplantation with post-transplantation cyclophosphamide and antithymocyte globulin from hla-mismatched related donors for nonmalignant diseases. Biol Blood Marrow Transplant: J Am Soc Blood Marrow Transplant. 2020. https://doi.org/10.1016/j.bbmt. 2020.08.008. e-pub ahead of print 2020/08/18

17. Kanakry CG, Fuchs EJ, Luznik L. Modern approaches to HLAhaploidentical blood or marrow transplantation. Nat Rev Clin Oncol. 2016;13:10-24. https://doi.org/10.1038/nrclinonc.2015. 128. e-pub ahead of print $2015 / 08 / 26$

18. Teltschik HM, Heinzelmann F, Gruhn B, Feuchtinger T, Schlegel $\mathrm{P}$, Schumm M, et al. Treatment of graft failure with TNI-based reconditioning and haploidentical stem cells in paediatric patients. Br J Haematol. 2016;175:115-122. https://doi.org/10.1111/bjh. 14190. e-pub ahead of print 2016/06/25

19. Prata PH, Resche-Rigon M, Blaise D, Socié G, Rohrlich PS, Milpied N, et al. Outcomes of salvage haploidentical transplant with post-transplant cyclophosphamide for rescuing graft failure patients: a report on behalf of the francophone society of bone marrow transplantation and cellular therapy. Biol Blood Marrow Transplant: J Am Soc Blood Marrow Transplant. 2019;25:1798-1802. https://doi.org/10.1016/j.bbmt.2019.05.013. e-pub ahead of print 2019/05/28

20. Meadows AT, Friedman DL, Neglia JP, Mertens AC, Donaldson SS, Stovall M, et al. Second neoplasms in survivors of childhood cancer: findings from the Childhood Cancer Survivor Study cohort. J Clin Oncol. 2009;27:2356-2362. https://doi.org/10. 1200/jco.2008.21.1920. e-pub ahead of print 2009/03/04

21. Przepiorka D, Weisdorf D, Martin P, Klingemann HG, Beatty P, Hows J, et al. 1994 Consensus Conference on Acute GVHD Grading. Bone Marrow Transplant. 1995;15:825-828. e-pub ahead of print 1995/06/01

22. Filipovich AH, Weisdorf D, Pavletic S, Socie G, Wingard JR, Lee SJ, et al. National Institutes of Health consensus development project on criteria for clinical trials in chronic graft-versus-host disease: I. Diagnosis and staging working group report. Biol Blood Marrow Transplant: J Am Soc Blood Marrow Transplant. 2005;11:945-956. https://doi.org/10.1016/j.bbmt.2005.09.004. epub ahead of print 2005/12/13

23. Zalewski NL, Tobin WO. CLIPPERS. Curr Neurol Neurosci Rep. 2017;17:65 https://doi.org/10.1007/s11910-017-0773-7. e-pub ahead of print 2017/07/21

24. Luznik L, O'Donnell PV, Symons HJ, Chen AR, Leffell MS, Zahurak M, et al. HLA-haploidentical bone marrow transplantation for hematologic malignancies using nonmyeloablative conditioning and high-dose, posttransplantation cyclophosphamide. Biol Blood Marrow Transplant: J Am Soc Blood Marrow Transplant. 2008;14:641-650. https://doi.org/10.1016/j.bbmt. 2008.03.005. e-pub ahead of print 2008/05/21 
25. Harada K, Fuji S, Seo S, Kanda J, Ueki T, Kimura F, et al. Comparison of the outcomes after haploidentical and cord blood salvage transplantations for graft failure following allogeneic hematopoietic stem cell transplantation. Bone marrow Transplant. 2020;55:1784-1795. https://doi.org/10.1038/s41409-020-0821-9. e-pub ahead of print 2020/02/14

26. Admiraal R, Jol-van der Zijde CM, Furtado Silva JM, CAJ Knibbe, Lankester AC, Boelens JJ, et al. Population pharmacokinetics of alemtuzumab (Campath) in pediatric hematopoietic cell transplantation: towards individualized dosing to improve outcome. Clin Pharmacokinetics. 2019;58:1609-1620. https://doi.org/10.1007/ s40262-019-00782-0. e-pub ahead of print 2019/05/28

27. Marsh RA, Lane A, Mehta PA, Neumeier L, Jodele S, Davies SM, et al. Alemtuzumab levels impact acute GVHD, mixed chimerism, and lymphocyte recovery following alemtuzumab, fludarabine, and melphalan RIC HCT. Blood. 2016;127:503-512. https://doi. org/10.1182/blood-2015-07-659672. e-pub ahead of print 2015/ $12 / 09$

28. Baker D, Marta M, Pryce G, Giovannoni G, Schmierer K. Memory B cells are major targets for effective immunotherapy in relapsing multiple sclerosis. EBioMedicine. 2017;16:41-50. https://doi.org/10.1016/j.ebiom.2017.01.042. e-pub ahead of print 2017/02/06

29. Mehra NK, Baranwal AK. Clinical and immunological relevance of antibodies in solid organ transplantation. Int J immunogenetics. 2016;43:351-368. https://doi.org/10.1111/iji.12294. e-pub ahead of print 2016/11/22

30. Yoshihara S, Ikegame K, Taniguchi K, Kaida K, Kim EH, Nakata $\mathrm{J}$, et al. Salvage haploidentical transplantation for graft failure using reduced-intensity conditioning. Bone Marrow Transplant. 2012;47:369-373. https://doi.org/10.1038/bmt.2011.84. e-pub ahead of print 2011/04/12

31. Moscardó F, Romero S, Sanz J, Sanz MA, Montesinos P, Lorenzo I, et al. T cell-depleted related HLA-mismatched peripheral blood stem cell transplantation as salvage therapy for graft failure after single unit unrelated donor umbilical cord blood transplantation. Biol Blood Marrow Transplant: J Am Soc Blood Marrow Transplant. 2014;20:1060-1063. https://doi.org/10.1016/j.bbmt. 2014.03.024. e-pub ahead of print 2014/04/02

32. Tang BL, Zhu XY, Zheng CC, Liu HL, Geng LQ, Wang XB, et al. Successful early unmanipulated haploidentical transplantation with reduced-intensity conditioning for primary graft failure after cord blood transplantation in hematologic malignancy patients. Bone Marrow Transplant. 2015;50:248-252. https://doi. org/10.1038/bmt.2014.250. e-pub ahead of print 2014/11/05

33. Yahng SA, Park SS, Jeon YW, Yoon JH, Shin SH, Lee SE, et al. Successful outcomes of second hematopoietic stem cell transplantation with total nodal irradiation and ATG conditioning for graft failure in adult patients with severe aplastic anemia. Bone Marrow Transplant. 2018;53:1270-1277. https://doi.org/10.1038/ s41409-018-0154-0. e-pub ahead of print 2018/03/23

34. Park JA, Koh KN, Choi ES, Jang S, Kwon SW, Park CJ, et al. Successful rescue of early graft failure in pediatric patients using T-cell-depleted haploidentical hematopoietic SCT. Bone Marrow Transplant. 2014;49:270-275. https://doi.org/10.1038/bmt.2013. 163. e-pub ahead of print 2013/10/22

35. Storb R, Doney KC, Thomas ED, Appelbaum F, Buckner CD, Clift RA, et al. Marrow transplantation with or without donor buffy coat cells for 65 transfused aplastic anemia patients. Blood. 1982;59:236-246. e-pub ahead of print 1982/02/01

36. Eapen M, Giralt SA, Horowitz MM, Klein JP, Wagner JE, Zhang MJ, et al. Second transplant for acute and chronic leukemia relapsing after first HLA-identical sibling transplant. Bone Marrow Transplant. 2004;34:721-727. https://doi.org/10.1038/sj.bmt. 1704645. e-pub ahead of print 2004/08/24

37. Eyrich M, Lang P, Lal S, Bader P, Handgretinger R, Klingebiel T, et al. A prospective analysis of the pattern of immune reconstitution in a paediatric cohort following transplantation of positively selected human leucocyte antigen-disparate haematopoietic stem cells from parental donors. $\mathrm{Br} \mathrm{J}$ Haematol. 2001;114:422-432. https://doi.org/10.1046/j.1365-2141.2001. 02934.x. e-pub ahead of print 2001/09/01

38. Lang P, Feuchtinger T, Teltschik HM, Schwinger W, Schlegel P, Pfeiffer $\mathrm{M}$, et al. Improved immune recovery after transplantation of TCR $\alpha \beta / C D 19$-depleted allografts from haploidentical donors in pediatric patients. Bone Marrow Transplant. 2015;50:S6-10. https://doi.org/10.1038/bmt.2015.87. e-pub ahead of print 2015/ $06 / 04$

39. Raiola AM, Dominietto A, di Grazia C, Lamparelli T, Gualandi F, Ibatici A, et al. Unmanipulated haploidentical transplants compared with other alternative donors and matched sibling grafts. Biol Blood Marrow Transplant: J Am Soc Blood Marrow Transplant. 2014;20:1573-1579. https://doi.org/10.1016/j.bbmt. 2014.05.029. e-pub ahead of print 2014/06/10 